\title{
Decorin, a growth hormone-regulated protein in humans
}

\author{
Neha Bahl1,2, Glenn Stone3, Mark McLean², Ken K Y Ho ${ }^{1,4}$ and Vita Birzniece ${ }^{1,2,5}$ \\ ${ }^{1}$ Garvan Institute of Medical Research, Sydney, New South Wales, Australia, ${ }^{2}$ School of Medicine, Western Sydney \\ University, Blacktown Clinical School and Research Centre, Blacktown Hospital, Blacktown, New South Wales, \\ Australia, ${ }^{3}$ School of Computing, Engineering and Mathematics, Western Sydney University, Penrith, New South \\ Wales, Australia, ${ }^{4}$ Centres of Health Research, Princess Alexandra Hospital, Brisbane, Queensland, Australia, and \\ ${ }^{5}$ School of Medicine, University of New South Wales, New South Wales, Australia
}

\author{
Correspondence \\ should be addressed \\ to $\mathrm{V}$ Birzniece \\ Email \\ v.birzniece@westernsydney. \\ edu.au
}

\begin{abstract}
Context: Growth hormone (GH) stimulates connective tissue and muscle growth, an effect that is potentiated by testosterone. Decorin, a myokine and a connective tissue protein, stimulates connective tissue accretion and muscle hypertrophy. Whether $\mathrm{GH}$ and testosterone regulate decorin in humans is not known.

Objective: To determine whether decorin is stimulated by $\mathrm{GH}$ and testosterone.

Design: Randomized, placebo-controlled, double-blind study.

Participants and Intervention: 96 recreationally trained athletes (63 men, 33 women) received 8 weeks of treatment followed by a 6 -week washout period. Men received placebo, GH ( $2 \mathrm{mg} /$ day), testosterone $(250 \mathrm{mg} /$ week) or combination. Women received either placebo or $\mathrm{GH}(2 \mathrm{mg} / \mathrm{day})$.

Main outcome measure: Serum decorin concentration.

Results: GH treatment significantly increased mean serum decorin concentration by $12.7 \pm 4.2 \% ; P<0.01$. There was a gender difference in the decorin response to $\mathrm{GH}$, with greater increase in men than in women $(\triangle 16.5 \pm 5.3 \%$; $P<0.05$ compared to $\Delta 9.4 \pm 6.5 \% ; P=0.16)$. Testosterone did not significantly change serum decorin. Combined GH and testosterone treatment increased mean decorin concentration by $19.5 \pm 3.7 \%(P<0.05)$, a change not significantly different from $\mathrm{GH}$ alone.
\end{abstract}

Conclusion: GH significantly increases circulating decorin, an effect greater in men than in women. Decorin is not affected by testosterone. We conclude that GH positively regulates decorin in humans in a gender-dimorphic manner.

\section{Introduction}

Growth hormone (GH) and testosterone are potent anabolic hormones that interact positively in regulating the muscle structure and function $(1,2,3,4)$. The effects of GH on collagen synthesis, fat mass, lean tissue and physical function are amplified by testosterone. Similarly the effects of testosterone in hypopituitary and normal men are greater when co-administered with GH $(4,5,6,7,8,9)$. Both GH and testosterone increase collagen markers, with GH imparting a greater effect, whereas testosterone amplifies the effect of GH on collagen markers, such as PIIINP $(4,5)$.
Decorin, a small leucine-rich proteoglycan, is a myokine and connective tissue protein $(10,11)$. Decorin is produced in response to exercise, and it stimulates skeletal muscle differentiation and repair $(12,13,14,15$, 16). Decorin induces myogenic satellite cell proliferation by inhibiting responsiveness to TGF- $\beta 1$ (17). In vitro overexpression of decorin enhances the proliferation and differentiation of skeletal muscle cells by repressing the activity of myostatin, an inhibitor of muscle cell growth and differentiation (18). Furthermore, decorin 
overexpression in muscle increases the expression of promyogenic genes, while repressing genes involved in muscle atrophy (16). Decorin also stimulates connective tissue collagen synthesis and regulates connective tissue formation in skeletal muscle $(19,20,21)$.

No studies to date have assessed the effects of GH or testosterone on decorin production in humans. The aim of the present study is to investigate whether GH and testosterone regulate circulating decorin in healthy men and women.

\section{Subjects and methods}

Healthy recreational athletes aged $18-40$ years, who had regularly participated in at least twice weekly exercise sessions in the past year were recruited, as previously described (5). Exclusion criteria were participation in sports competitions at the state or national level, selfreported abuse of performance-enhancing drugs, history of diabetes mellitus, cardiovascular, hepatic or renal disease, known cancer or positive urine screen for prohibited anabolic agents. 96 athletes (63 men and 33 women) were included in the study. Participants were instructed not to change their diet or exercise level throughout the study. All study participants provided written informed consent. The study was approved by St. Vincent's Hospital Human Research Ethics Committee, NSW Australia and registered with the Australian New Zealand Clinical Trials Registry ACTRN012605000508673.

This was a double-blind placebo-controlled randomized study, as previously described (5). Briefly, women were assigned to receive either $2 \mathrm{mg}$ /day GH $(n=17)$ or placebo $(n=16)$. Men were assigned to receive $2 \mathrm{mg} /$ day GH $(n=15), 250 \mathrm{mg} /$ week testosterone $(n=16)$, GH plus testosterone $(n=16)$, or double placebo $(n=16)$. Participants self-administered GH (Somatropin, $1 \mathrm{mg} / \mathrm{mL}$;
Novo Nordisk) or matched placebo subcutaneously each evening at dosages of $1.0 \mathrm{mg} /$ day in the first week, $1.5 \mathrm{mg} /$ day in the second week and $2.0 \mathrm{mg} /$ day for the remaining 6 weeks. Testosterone (Sustanon, Organon, Oss, the Netherlands; $250 \mathrm{mg} /$ week) or placebo was administered from the end of the third week as weekly intramuscular injections (5). The effects of the interventions on IGFI, collagen peptides, body composition and physical function have been published $(4,5)$.

We examined whether serum decorin concentrations were affected by supplementation with GH in men and women, and testosterone in men. We also investigated whether co-administration with testosterone enhanced the effects of GH alone. We compared changes in decorin to GH-regulated proteins, IGF-I and collagen peptides and changes in body composition. Body composition was measured by dual-energy $\mathrm{x}$-ray absorptiometry and included lean body mass (LBM) assessment and a functional measure of muscle mass - body cell mass (derived by subtracting extracellular water from the LBM), as previously described (4).

\section{Assays}

Serum samples were collected at baseline (week 0), during treatment (week 4), end of treatment (week 8) and after a 6-week washout period (week 14) and stored at $-80^{\circ} \mathrm{C}$ for analysis. Decorin levels were measured using the Decorin Human ELISA kit (Abcam) according to manufacturer instructions. Serum samples were diluted 100-fold and all samples for each subject were measured in duplicates in the same assay run. The sensitivity of the assay is $<1.5 \mathrm{pg} / \mathrm{mL}$ with $>93 \%$ recovery rate. The intra-assay and inter-assay coefficients of variation (CVs) were $<2 \%$ and $<12 \%$, respectively. IGF-1, testosterone, PINP, PIIINP and ICTP were assayed as previously described (5).

Table 1 Baseline characteristics of the study subjects. The table shows the age, body mass index (BMI), and serum levels of IGF-1, testosterone, PIIINP and decorin of the subjects in various treatment groups. Data are shown as mean \pm S.E.M.

\begin{tabular}{|c|c|c|c|c|c|c|}
\hline Treatment & Age (year) & BMI $\left(\mathrm{kg} / \mathrm{m}^{2}\right)$ & IGF-1 ( $\mu \mathrm{g} / \mathrm{L})$ & $\mathbf{T}(\mathrm{nmol} / \mathrm{L})$ & PIIINP $(\mu \mathrm{g} / \mathrm{L})$ & Decorin $(\mathrm{pg} / \mathrm{mL})$ \\
\hline \multicolumn{7}{|l|}{ Women } \\
\hline Placebo & $27.8 \pm 1.3$ & $22.8 \pm 0.8$ & $137 \pm 10.0$ & $1.4 \pm 0.2$ & $4.5 \pm 0.3$ & $6481 \pm 203$ \\
\hline $\mathrm{GH}$ & $29.7 \pm 1.6$ & $22.9 \pm 0.7$ & $124 \pm 7.9$ & $1.2 \pm 0.2$ & $3.7 \pm 0.2$ & $6127 \pm 349$ \\
\hline \multicolumn{7}{|l|}{ Men } \\
\hline Placebo & $28.9 \pm 1.3$ & $26.1 \pm 0.8$ & $110 \pm 9.6$ & $21.9 \pm 1.9$ & $3.4 \pm 0.2$ & $5748 \pm 275$ \\
\hline GH & $25.2 \pm 1.4$ & $23.8 \pm 0.7$ & $128 \pm 9.7$ & $25.3 \pm 2.1$ & $4.2 \pm 0.4$ & $5748 \pm 269$ \\
\hline $\mathbf{T}$ & $29.0 \pm 1.5$ & $25.4 \pm 1.0$ & $128 \pm 9.5$ & $23.5 \pm 2.0$ & $4.1 \pm 0.3$ & $6304 \pm 448$ \\
\hline $\mathrm{GH}+\mathrm{T}$ & $26.8 \pm 1.3$ & $24.4 \pm 0.7$ & $113 \pm 10.3$ & $23.1 \pm 1.3$ & $4.0 \pm 0.2$ & $5953 \pm 312$ \\
\hline
\end{tabular}

www.eje-online.org 


\section{Statistical analysis}

Treatment effects on decorin levels were evaluated by oneway ANOVA for repeated measures, followed by Dunnett's post hoc multiple comparison test to evaluate treatment effects at individual time points. Data are expressed as mean \pm s.E.m. Multiplicity adjusted $P$ values are reported, and differences relative to the placebo group considered significant at $P<0.05$. Spearman's rank correlation was used for the analysis of correlation between the serum decorin concentration and the IGF axis, collagen markers and body composition. Unadjusted $P$ values are reported, and correlations were considered significant at $P<0.05$. Statistical analyses were performed using RStudio (Boston, MA, USA) (22).

\section{Results}

Table 1 shows the baseline characteristics of the 96 subjects, serum concentration of decorin, and previously reported measures of body mass index (BMI), IGF-1 and PIIINP (5). There were no significant differences in the baseline decorin levels between the treatment groups. At baseline, there was a positive and significant correlation between serum levels of decorin and the collagen marker, PIIINP $(R=0.34, P<0.01)$. There were no significant associations between baseline serum decorin concentrations and any other endpoint measures.

Indicative of the effect of intervention, in women $\mathrm{GH}$ administration increased IGF-1 by $86 \pm 12 \%(P<0.0001)$. In men, IGF-1 significantly $(P<0.0001)$ increased by $144 \pm 23 \%$ and $160 \pm 24 \%$ when treated with GH alone or when combined with testosterone, respectively. Serum testosterone increased significantly $(P<0.01)$ in men treated with testosterone alone $(23.5 \pm 2.0$ vs $32.2 \pm 2.5 \mathrm{nmol} / \mathrm{L})$ or when combined with $\mathrm{GH}(23.1 \pm 1.3$ vs $31.2 \pm 1.7 \mathrm{nmol} / \mathrm{L})$.

Table 2 shows serum decorin levels during the hormone treatments and withdrawal. The mean decorin concentration increased significantly $(P<0.01)$ during eight weeks of GH treatment, returning to baseline after withdrawal (Fig. 1A). The increase in decorin concentration was greater in men $(16.5 \pm 5.3 \% ; P<0.05$, Fig. $1 C)$ than in women $(9.4 \pm 6.5 \% ; P=0.16$; Fig. 1B). Decorin levels did not change during placebo treatment. Testosterone treatment did not significantly affect circulating decorin levels ( $\Delta 4.2 \pm 3.6 \% ; P=0.30$; Fig. 2). Co-administration of testosterone with $\mathrm{GH}$ significantly increased decorin levels ( $\Delta 19.5 \pm 3.7 \% P<0.01$; Fig. 2 ). However, no additive effect of the co-treatment was observed compared to GH alone.

Changes in serum decorin correlated significantly $(P<0.001)$ with changes in IGF-1, PINP, ICTP and PIIINP (Fig. 3). Changes in serum decorin showed significant positive correlation with changes in LBM $(R=0.50$; $P<0.001)$ and body cell mass $(R=0.31 ; P<0.05)$.

\section{Discussion}

This study investigated whether decorin is regulated by GH or testosterone in humans. Our data demonstrate that GH significantly increases serum decorin concentration with the effect greater in men than in women. Testosterone did not affect decorin and co-treatment did not have additional effect to that of $\mathrm{GH}$ alone. The changes in decorin induced by GH correlated with those of other GH-responsive proteins in blood.

Table 2 Mean serum decorin concentrations before treatment (week 0), during treatment (week 4), end of treatment (week 8) and after a 6-week washout period (week 14). Men received either placebo, GH (2 mg/day), testosterone ( $250 \mathrm{mg} / \mathrm{week})$, or combined treatments. Women received either placebo or $\mathrm{GH}(2 \mathrm{mg} /$ day). Data are shown as mean \pm S.E.M.

\begin{tabular}{|c|c|c|c|c|c|c|}
\hline & \multirow[b]{2}{*}{$n$} & \multirow[b]{2}{*}{ Treatment } & \multicolumn{4}{|c|}{ Serum decorin $(\mathrm{pg} / \mathrm{mL})$} \\
\hline & & & Week 0 & Week 4 & Week 8 & Week 14 \\
\hline \multirow[t]{2}{*}{ Women and men } & 32 & Placebo & $6114 \pm 181$ & $6075 \pm 216$ & $6017 \pm 185$ & $5838 \pm 225$ \\
\hline & 32 & $\mathrm{GH}$ & $5950 \pm 223$ & $6452 \pm 269^{a}$ & $6652 \pm 312^{a}$ & $5931 \pm 252^{b}$ \\
\hline \multirow[t]{2}{*}{ Women } & 16 & Placebo & $6481 \pm 203$ & $6220 \pm 329$ & $6218 \pm 220$ & $6189 \pm 300$ \\
\hline & 17 & $\mathrm{GH}$ & $6127 \pm 349$ & $6491 \pm 364$ & $6591 \pm 434$ & $5902 \pm 352^{b}$ \\
\hline \multirow[t]{4}{*}{ Men } & 16 & Placebo & $5748 \pm 275$ & $5930 \pm 285$ & $5816 \pm 297$ & $5487 \pm 320$ \\
\hline & 15 & $\mathrm{GH}$ & $5748 \pm 269$ & $6408 \pm 413$ & $6721 \pm 465^{a}$ & $5965 \pm 373^{b}$ \\
\hline & 16 & $\mathrm{~T}$ & $6304 \pm 448$ & $6664 \pm 505$ & $6547 \pm 492$ & $5937 \pm 426^{b}$ \\
\hline & 16 & $\mathrm{GH}+\mathrm{T}$ & $5953 \pm 312$ & $6600 \pm 355^{a}$ & $7061 \pm 368^{a}$ & $5438 \pm 250^{b}$ \\
\hline
\end{tabular}

${ }^{a}$ Decorin significantly different from week 0 within group $(P<0.05)$; becorin at week 14 significantly different from week 8 within group $(P<0.05)$. $\mathrm{GH}$, growth hormone; T, testosterone. 
A

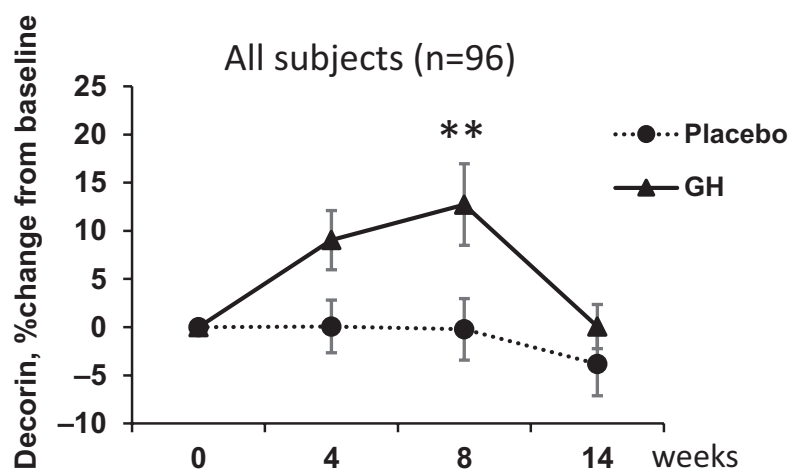

B

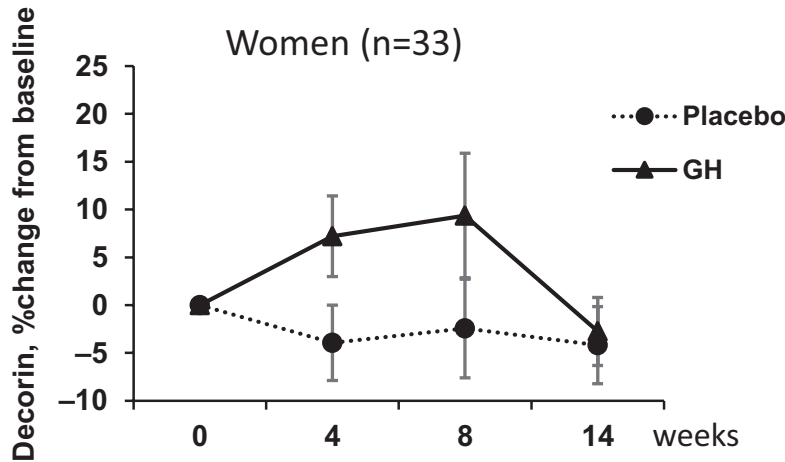

C

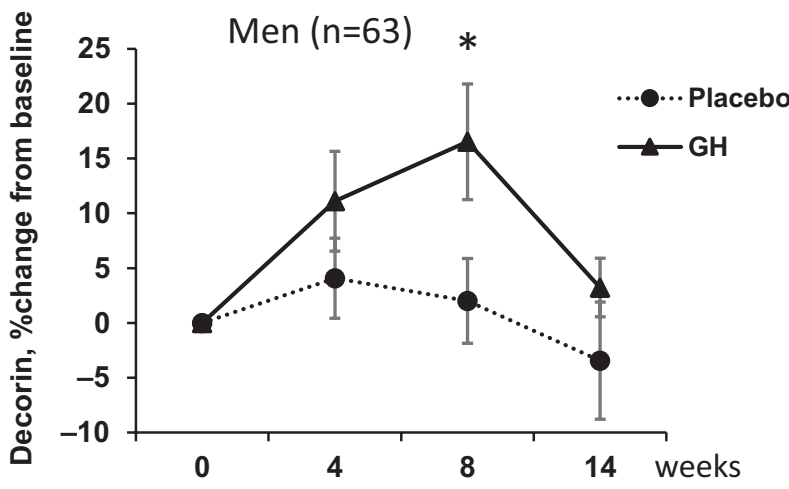

Figure 1

Change in serum decorin concentration in men and women in response to hormone treatment. Data are presented as mean percentage changes in serum decorin at week 4 (during treatment), week 8 (end of treatment) and week 14 (after a 6-week washout period) from baseline (week 0) for: (A) GH treatment group (men and women combined), (B) women and (C) men. Data are mean \pm S.E.M. ${ }^{*} P<0.05, * * P<0.01$.

Very little is known about decorin regulation by GH or testosterone. To our knowledge, only one previous study undertaken in rodents observed an increase in decorin

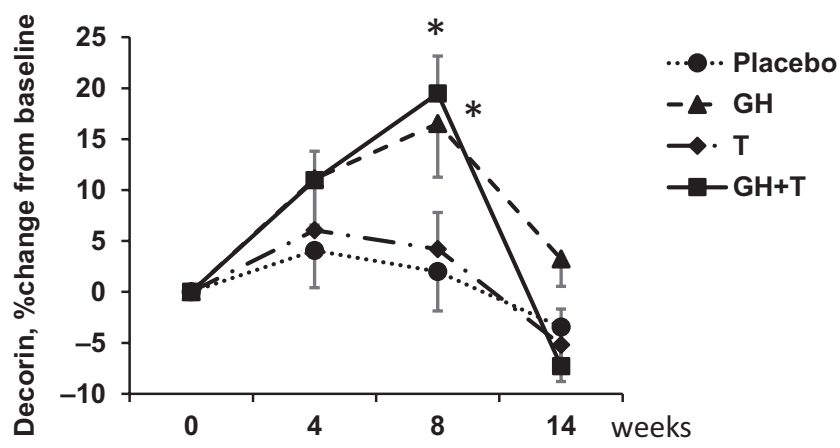

Figure 2

Change in serum decorin concentration in men in response to hormone treatment. Mean percentage changes in serum decorin at week 4 (during treatment), week 8 (end of treatment) and week 14 (after a 6-week washout period) from baseline (week 0 ). Data are shown as mean \pm S.E.M. ${ }^{\star} P<0.05$.

production in the extracellular matrix of developing incisors in response to $\mathrm{GH}$ (23). In young males, GH administration for 2 weeks did not affect decorin mRNA expression in tendon during immobilization; however, circulating decorin was not measured (24). Thus, our study is the first to report that GH stimulates decorin production in humans.

Decorin is a structural protein in the skeletal muscle extracellular matrix and regulates genes for muscle growth and repair $(16,18)$, suggesting a role in the regulation of muscle structure and function. There is strong evidence that exercise positively regulates decorin gene expression and protein production in muscle, contributing to a rise in blood decorin during exercise $(15,16)$. Because exercise also stimulates the release of GH $(25,26)$, our findings provide evidence that the stimulation of decorin production may in part be GH mediated.

As decorin stimulates collagen fibrillogenesis (11), we postulate that the upregulation of decorin by GH may play a role in collagen tissue anabolism. GH stimulates muscle and tendon collagen synthesis $(24,27)$, and we have previously reported that GH significantly increases the markers PINP and PIIINP, indicative of collagen synthesis (5). Thus, GH exerts a significant positive effect on collagen tissue formation. Decorin is known to play a role in collagen formation and has been shown to bind to collagen types I and III $(28,29)$. In our study, decorin levels correlated with those of PIIINP, which has particular importance in bone and tendon tissue repair (30). Furthermore, decorin modulates bone collagen matrix assembly and mineralization (31). Thus, decorin plays a role in the structural properties of muscle and bone by 

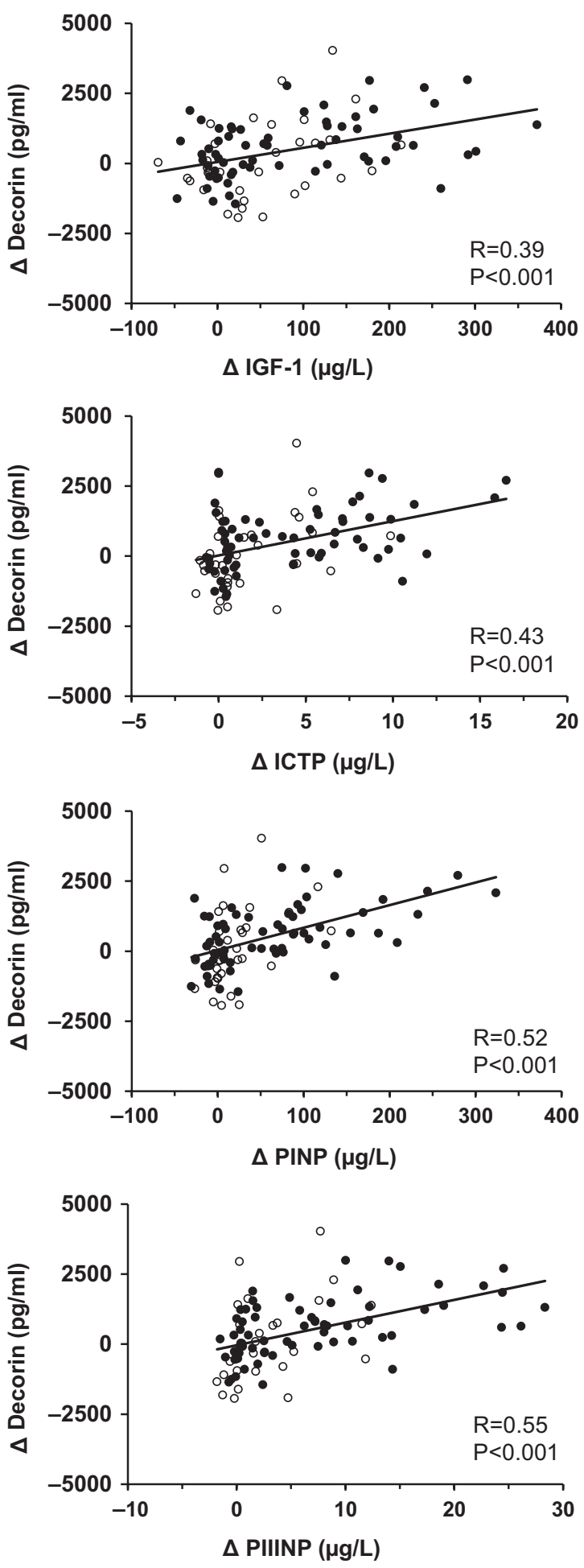

Figure 3

Relation between changes in serum decorin concentrations at week 8 from baseline, vs the changes in IGF-1, PINP, ICTP, and PIIINP in men (solid circles) and women (clear circles). The Spearman correlation coefficients and $P$ values are indicated for each correlation. positively regulating collagen synthesis, an effect which is co-regulated by GH.

We observed a greater increase in decorin levels in men than in women, in the face of a lower body weight-adjusted dose of GH in men than in women. The actions of GH on a range of biological effects are sexually dimorphic $(32,33,34,35)$. In GH-deficient adults, men are more sensitive to GH replacement therapy than women and exhibit significantly greater responses to GH with regard to IGF-1, body composition and bone metabolism markers $(36,37,38,39)$. This clinically significant gender difference may be attributed to the inhibitory effects of estrogens on the GH receptor signaling in women (40). In this study, GH therapy increased collagen markers (PINP, ICTP, PIIINP) to a much greater extent in men than in women (5). As decorin also is a connective tissue protein, the greater increase in decorin in men could relate to the well-known gender difference in the response to GH.

The gender difference in decorin cannot be explained by testosterone because we did not observe an effect of testosterone either alone or co-administered with GH. Testosterone is a potent stimulator of skeletal muscle anabolism, dose dependently increasing muscle mass (1, $2,3)$. Although testosterone substantially amplifies the GH effect on collagen marker PIIINP (5), we observed no significant effect on decorin by the co-administration of these hormones. This implies minimal physiological effect of testosterone on circulating decorin in men.

GH may exert its anabolic effects directly through its receptor or indirectly via actions mediated by IGF1. Besides increasing the levels of circulating IGF-1, GH stimulates the local production of IGF-1 in tissues such as muscle, tendon and cartilage $(41,42)$. Our study design does not allow to differentiate GH and IGF-1 effect on decorin. In vitro reports suggest that IGF-1 stimulates decorin production in a dose-dependent manner $(43,44$, 45). Furthermore, connective tissue growth factor (CTGF) is an inducer of decorin synthesis (46) and has been shown to bind to IGF-1 to enhance its effects on collagen (47). In Laron syndrome of GH insensitivity, IGF-1 administration increases circulating collagen markers, providing evidence that IGF-1 plays an important role in connective tissue metabolism (48). As decorin levels change in parallel to other connective tissue markers, it is plausible that IGF-1 directly stimulates decorin production. Thus, GH through IGF-1 may regulate circulating decorin.

IGF-1 and PIIINP are endorsed biomarkers for $\mathrm{GH}$ doping. In our study, the peak response to GH administration in men was around $140 \%$ and $250 \%$ increase for IGF-1 and PIIINP, respectively (5). Decorin 
levels increased by $16.5 \%$ during $\mathrm{GH}$ administration at supraphysiological doses. After 6 weeks of withdrawal from GH, collagen markers (PINP, ICTP and PIIINP) were significantly higher in the $\mathrm{GH}$ group compared to placebo (5), whereas decorin returned to baseline upon $\mathrm{GH}$ withdrawal. Furthermore, the rather small increase and large variation in decorin during $\mathrm{GH}$ administration in women also indicates that decorin may not have a potential to be used as a marker for GH doping in sport.

There are some limitations to our study. Serum levels of decorin may not reflect tissue concentration of decorin. Furthermore, the effect of testosterone may be apparent if different doses or duration of testosterone administration had been used or patients with hypogonadism are studied instead of healthy adults. Nevertheless, we observed no significant effect on circulating decorin using supraphysiological doses of intramuscular testosterone administration 3-4 times that of normal production rate, indicating that in healthy adults testosterone supplementation does not increase circulating decorin.

In summary, we show that administration of GH in healthy adults increases circulating decorin, with the effect greater in men than in women. Testosterone has no significant effect on decorin concentration. We conclude that $\mathrm{GH}$ increases serum decorin levels in a genderdependent manner. We postulate that the upregulation of decorin by $\mathrm{GH}$ may play a role in collagen tissue anabolism, enhancing the structural properties of muscle, tendon and bone.

\section{Declaration of interest}

The authors declare that there is no conflict of interest that could be perceived as prejudicing the impartiality of this study.

Funding

World Anti-Doping Agency and the Australian Government.

\section{Acknowledgements}

The authors thank all volunteers for their participation in the study; research nurses for clinical assistance; Udo Meinhardt, Anne Nelson, David Clifford, Kin-Chuen Leung, Irene Walker and Kenneth Graham for their input in the original study. Funding was provided by the World AntiDoping Agency and the Australian Government (through the Anti-Doping Research Program of the Department of Communications, Information Technology and the Arts)

\section{References}

1 Kadi F. Cellular and molecular mechanisms responsible for the action of testosterone on human skeletal muscle. A basis for illegal performance enhancement. British Journal of Pharmacology 2008154 522-528. (https://doi.org/10.1038/bjp.2008.118)

2 Bhasin S, Woodhouse L, Casaburi R, Singh AB, Bhasin D, Berman N, Chen X, Yarasheski KE, Magliano L, Dzekov C et al. Testosterone dose-response relationships in healthy young men. American Journal of Physiology: Endocrinology and Metabolism 2001281 E1172-E1181.

3 Woodhouse LJ, Gupta N, Bhasin M, Singh AB, Ross R, Phillips J $\&$ Bhasin S. Dose-dependent effects of testosterone on regional adipose tissue distribution in healthy young men. Journal of Clinical Endocrinology and Metabolism 200489 718-726. (https://doi. org/10.1210/jc.2003-031492)

4 Meinhardt U, Nelson AE, Hansen JL, Birzniece V, Clifford D, Leung KC, Graham K \& Ho KK. The effects of growth hormone on body composition and physical performance in recreational athletes: a randomized trial. Annals of Internal Medicine 2010152 568-577. (https://doi.org/10.7326/0003-4819-152-9-201005040-00007)

5 Nelson AE, Meinhardt U, Hansen JL, Walker IH, Stone G, Howe CJ, Leung KC, Seibel MJ, Baxter RC, Handelsman DJ et al. Pharmacodynamics of growth hormone abuse biomarkers and the influence of gender and testosterone: a randomized double-blind placebo-controlled study in young recreational athletes. Journal of Clinical Endocrinology and Metabolism 200893 2213-2222. (https:// doi.org/10.1210/jc.2008-0402)

6 Keenan BS, Richards GE, Ponder SW, Dallas JS, Nagamani M \& Smith ER. Androgen-stimulated pubertal growth: the effects of testosterone and dihydrotestosterone on growth hormone and insulin-like growth factor-I in the treatment of short stature and delayed puberty. Journal of Clinical Endocrinology and Metabolism 1993 76 996-1001.

7 Gibney J, Wolthers T, Johannsson G, Umpleby AM \& Ho KK. Growth hormone and testosterone interact positively to enhance protein and energy metabolism in hypopituitary men. American Journal of Physiology: Endocrinology and Metabolism 2005289 E266-E271. (https://doi.org/10.1152/ajpendo.00483.2004)

8 Johannsson G, Gibney J, Wolthers T, Leung KC \& Ho KK. Independent and combined effects of testosterone and growth hormone on extracellular water in hypopituitary men. Journal of Clinical Endocrinology and Metabolism 200590 3989-3994. (https:// doi.org/10.1210/jc.2005-0553)

9 Birzniece V, Meinhardt UJ, Umpleby MA, Handelsman DJ \& Ho KK. Interaction between testosterone and growth hormone on wholebody protein anabolism occurs in the liver. Journal of Clinical Endocrinology and Metabolism 201196 1060-1067. (https://doi. org/10.1210/jc.2010-2521)

10 Brandan E, Fuentes ME \& Andrade W. The proteoglycan decorin is synthesized and secreted by differentiated myotubes. European Journal of Cell Biology 199155 209-216.

11 Danielson KG, Baribault H, Holmes DF, Graham H, Kadler KE \& Iozzo RV. Targeted disruption of decorin leads to abnormal collagen fibril morphology and skin fragility. Journal of Cell Biology 1997136 729-743. (https://doi.org/10.1083/jcb.136.3.729)

12 Bianco P, Fisher LW, Young MF, Termine JD \& Robey PG. Expression and localization of the two small proteoglycans biglycan and decorin in developing human skeletal and non-skeletal tissues. Journal of Histochemistry and Cytochemistry 199038 1549-1563. (https://doi. org/10.1177/38.11.2212616)

13 Henningsen J, Rigbolt KT, Blagoev B, Pedersen BK \& Kratchmarova I. Dynamics of the skeletal muscle secretome during myoblast differentiation. Molecular and Cellular Proteomics 20109 2482-2496. (https://doi.org/10.1074/mcp.M110.002113)

14 Li Y, Li J, Zhu J, Sun B, Branca M, Tang Y, Foster W, Xiao X \& Huard J. Decorin gene transfer promotes muscle cell differentiation and muscle regeneration. Molecular Therapy 200715 1616-1622. (https:// doi.org/10.1038/sj.mt.6300250)

15 Heinemeier KM, Bjerrum SS, Schjerling P \& Kjaer M. Expression of extracellular matrix components and related growth factors in 
human tendon and muscle after acute exercise. Scandinavian Journal of Medicine and Science in Sports 201323 e150-e161. (https://doi. org/10.1111/j.1600-0838.2011.01414.x)

16 Kanzleiter T, Rath M, Gorgens SW, Jensen J, Tangen DS, Kolnes AJ, Kolnes KJ, Lee S, Eckel J, Schurmann A et al. The myokine decorin is regulated by contraction and involved in muscle hypertrophy. Biochemical and Biophysical Research Communications 2014450 1089-1094. (https://doi.org/10.1016/j.bbrc.2014.06.123)

17 Li X, McFarland DC \& Velleman SG. Extracellular matrix proteoglycan decorin-mediated myogenic satellite cell responsiveness to transforming growth factor-beta1 during cell proliferation and differentiation Decorin and transforming growth factor-beta1 in satellite cells. Domestic Animal Endocrinology 200835 263-273. (https://doi.org/10.1016/j.domaniend.2008.06.002)

18 Kishioka Y, Thomas M, Wakamatsu J, Hattori A, Sharma M, Kambadur R \& Nishimura T. Decorin enhances the proliferation and differentiation of myogenic cells through suppressing myostatin activity. Journal of Cellular Physiology 2008215 856-867. (https://doi. org/10.1002/jcp.21371)

19 Vogel KG \& Trotter JA. The effect of proteoglycans on the morphology of collagen fibrils formed in vitro. Collagen and Related Research 19877 105-114. (https://doi.org/10.1016/S0174173X(87)80002-X)

20 Weber IT, Harrison RW \& Iozzo RV. Model structure of decorin and implications for collagen fibrillogenesis. Journal of Biological Chemistry 1996271 31767-31770.

21 Neame PJ, Kay CJ, McQuillan DJ, Beales MP \& Hassell JR. Independent modulation of collagen fibrillogenesis by decorin and lumican. Cellular and Molecular Life Sciences 200057 859-863. (https://doi.org/10.1007/s000180050048)

22 R Core Development Team. R: A Language and Environment for Statistical Computing. R Foundation for Statistical Computing. Vienna, Austria, 2015. Accessed from http://www.R-project.org/

23 Zhang CZ, Li H, Bartold PM, Young WG \& Waters MJ. Effect of growth hormone on the distribution of decorin and biglycan during odontogenesis in the rat incisor. Journal of Dental Research $1995 \mathbf{7 4}$ 1636-1643. (https://doi.org/10.1177/00220345950740100301)

24 Boesen AP, Dideriksen K, Couppe C, Magnusson SP, Schjerling P, Boesen M, Kjaer M \& Langberg H. Tendon and skeletal muscle matrix gene expression and functional responses to immobilisation and rehabilitation in young males: effect of growth hormone administration. Journal of Physiology 2013591 6039-6052. (https:// doi.org/10.1113/jphysiol.2013.261263)

25 Pritzlaff CJ, Wideman L, Weltman JY, Abbott RD, Gutgesell ME, Hartman ML, Veldhuis JD \& Weltman A. Impact of acute exercise intensity on pulsatile growth hormone release in men. Journal of Applied Physiology 199987 498-504.

26 Sutton J \& Lazarus L. Growth hormone in exercise: comparison of physiological and pharmacological stimuli. Journal of Applied Physiology 197641 523-527.

27 Doessing S, Heinemeier KM, Holm L, Mackey AL, Schjerling P, Rennie M, Smith K, Reitelseder S, Kappelgaard AM, Rasmussen MH et al. Growth hormone stimulates the collagen synthesis in human tendon and skeletal muscle without affecting myofibrillar protein synthesis. Journal of Physiology 2010588 341-351. (https://doi. org/10.1113/jphysiol.2009.179325)

28 Brown DC \& Vogel KG. Characteristics of the in vitro interaction of a small proteoglycan (PG II) of bovine tendon with type I collagen. Matrix 19899 468-478. (https://doi.org/10.1016/S09348832(11)80016-8)

29 Thieszen SL \& Rosenquist TH. Expression of collagens and decorin during aortic arch artery development: implications for matrix pattern formation. Matrix Biology 199514 573-582. (https://doi. org/10.1016/S0945-053X(05)80006-X)

30 Miedel EL, Brisson BK, Hamilton T, Gleason H, Swain GP, Lopas L, Dopkin D, Perosky JE, Kozloff KM, Hankenson KD et al.
Type III collagen modulates fracture callus bone formation and early remodeling. Journal of Orthopaedic Research 201533 675-684. (https://doi.org/10.1002/jor.22838)

31 Mochida Y, Parisuthiman D, Pornprasertsuk-Damrongsri S, Atsawasuwan P, Sricholpech M, Boskey AL \& Yamauchi M. Decorin modulates collagen matrix assembly and mineralization. Matrix Biology 200928 44-52. (https://doi.org/10.1016/j. matbio.2008.11.003)

32 Dall R, Longobardi S, Ehrnborg C, Keay N, Rosen T, Jorgensen JO, Cuneo RC, Boroujerdi MA, Cittadini A, Napoli R et al. The effect of four weeks of supraphysiological growth hormone administration on the insulin-like growth factor axis in women and men. GH-2000 Study Group. Journal of Clinical Endocrinology and Metabolism 200085 4193-4200.

33 Longobardi S, Keay N, Ehrnborg C, Cittadini A, Rosen T, Dall R, Boroujerdi MA, Bassett EE, Healy ML, Pentecost C et al. Growth hormone (GH) effects on bone and collagen turnover in healthy adults and its potential as a marker of GH abuse in sports: a double blind, placebo-controlled study. The GH-2000 Study Group. Journal of Clinical Endocrinology and Metabolism 200085 1505-1512.

34 Gotherstrom G, Bengtsson BA, Bosaeus I, Johannsson G \& Svensson J. A 10-year, prospective study of the metabolic effects of growth hormone replacement in adults. Journal of Clinical Endocrinology and Metabolism 200792 1442-1445. (https://doi. org/10.1210/jc.2006-1487)

35 Blackman MR, Sorkin JD, Munzer T, Bellantoni MF, BusbyWhitehead J, Stevens TE, Jayme J, O'Connor KG, Christmas C, Tobin JD et al. Growth hormone and sex steroid administration in healthy aged women and men: a randomized controlled trial. JAMA 2002288 2282-2292. (https://doi.org/10.1001/jama.288.18.2282)

36 Johansson AG. Gender difference in growth hormone response in adults. Journal of Endocrinological Investigation 199922 58-60.

37 Burman P, Johansson AG, Siegbahn A, Vessby B \& Karlsson FA. Growth hormone (GH)-deficient men are more responsive to GH replacement therapy than women. Journal of Clinical Endocrinology and Metabolism 199782 550-555.

38 Hayes FJ, Fiad TM \& McKenna TJ. Gender difference in the response of growth hormone (GH)-deficient adults to GH therapy. Metabolism 199948 308-313. (https://doi.org/10.1016/S00260495(99)90077-X)

39 Johannsson G, Bjarnason R, Bramnert M, Carlsson LM, Degerblad M, Manhem P, Rosen T, Thoren M \& Bengtsson BA. The individual responsiveness to growth hormone (GH) treatment in GH-deficient adults is dependent on the level of GH-binding protein, body mass index, age, and gender. Journal of Clinical Endocrinology and Metabolism 199681 1575-1581.

40 Leung KC, Johannsson G, Leong GM \& Ho KK. Estrogen regulation of growth hormone action. Endocrine Reviews 200425 693-721. (https://doi.org/10.1210/er.2003-0035)

41 Isgaard J, Nilsson A, Vikman K \& Isaksson OG. Growth hormone regulates the level of insulin-like growth factor-I mRNA in rat skeletal muscle. Journal of Endocrinology 1989120 107-112. (https://doi. org/10.1677/joe.0.1200107)

42 Sadowski CL, Wheeler TT, Wang LH \& Sadowski HB. GH regulation of IGF-I and suppressor of cytokine signaling gene expression in C2C12 skeletal muscle cells. Endocrinology 2001142 3890-3900. (https://doi.org/10.1210/endo.142.9.8365)

43 D'Avis PY, Frazier CR, Shapiro JR \& Fedarko NS. Age-related changes in effects of insulin-like growth factor I on human osteoblast-like cells. Biochemical Journal 1997324 753-760.

44 Mullen LM, Best SM, Ghose S, Wardale J, Rushton N \& Cameron RE. Bioactive IGF-1 release from collagen-GAG scaffold to enhance cartilage repair in vitro. Journal of Materials Science: Materials in Medicine 2015265325.

45 Holladay C, Abbah SA, O'Dowd C, Pandit A \& Zeugolis DI. Preferential tendon stem cell response to growth factor 
supplementation. Journal of Tissue Engineering and Regenerative Medicine 201610 783-798. (https://doi.org/10.1002/term.1852)

46 Vial C, Gutierrez J, Santander C, Cabrera D \& Brandan E. Decorin interacts with connective tissue growth factor (CTGF)/CCN2 by LRR12 inhibiting its biological activity. Journal of Biological Chemistry 2011286 24242-24252. (https://doi.org/10.1074/jbc.M110.189365)

47 Lam S, van der Geest RN, Verhagen NA, van Nieuwenhoven FA, Blom IE, Aten J, Goldschmeding R, Daha MR \& van Kooten C.
Connective tissue growth factor and igf-I are produced by human renal fibroblasts and cooperate in the induction of collagen production by high glucose. Diabetes 200352 2975-2983. (https:// doi.org/10.2337/diabetes.52.12.2975)

48 Klinger B, Jensen LT, Silbergeld A \& Laron Z. Insulin-like growth factor-I raises serum procollagen levels in children and adults with Laron syndrome. Clinical Endocrinology 199645 423-429. (https:// doi.org/10.1046/j.1365-2265.1996.7990809.x)

Received 12 October 2017

Revised version received 3 November 2017

Accepted 14 November 2017 